\title{
The Prevalence of Diabetes Mellitus and Abnormal Lipid Status among Croatian Hospitalized Coronary Heart Disease Patients
}

\author{
Hrvoje Vražić ${ }^{1}$, Tomo Lucijanić1,2, Jozica Šikić1,3, Ivana Rajčan Špoljarić1, Stojan Polić ${ }^{4}$, \\ Đivo Ljubičićc ${ }^{5}$ Katarina Matićc ${ }^{2}$, Tonći Božin², Irena Šubjak ${ }^{2}$ and Mijo Bergovec ${ }^{1,2}$ \\ ${ }^{1}$ University of Zagreb, Dubrava University Hospital, Department of Internal Medicine, Division of Cardiology, Zagreb, Croatia \\ ${ }^{2}$ University of Zagreb, School of Medicine, Zagreb, Croatia \\ ${ }^{3}$ University of Zagreb, Sveti Duh University Hospital, Department of Internal Medicine, Division of Cardiology, Zagreb, Croatia \\ ${ }^{4}$ University of Split, Split University Hospital Centre, Department of Internal Medicine, Division of Cardiology, Split, Croatia \\ ${ }^{5}$ University of Zagreb, Dubrava University Hospital, Department of Internal Medicine, Zagreb, Croatia
}

\begin{abstract}
A B S T R A C T
The aim of this article was to investigate the prevalence of diabetes mellitus and abnormal lipid status with selected anthropometric variables in a sample of hospitalized coronary heart disease (CHD) patients in Croatia $(N=1,298)$. Prevalence of diabetes mellitus was 31.6\% (statistically significantly more frequent in women, 35.7\% vs. $30.0 \%$ ), while prevalences of increased total cholesterol were $72.0 \%$, decreased HDL-cholesterol $42.6 \%$ (statistically significantly more frequent in women, $50.2 \%$ vs. $39.6 \%$ ), increased LDL-cholesterol $72.3 \%$ and increased triglycerides $51.5 \%$. Reported data on prevalences of diabetes mellitus can be somewhat reassuring (a decrease in its prevalence compared to data from 2006, but they still signal a situation which is a lot worse than in 2002 and 2003); the trend of rising prevalences of dyslipidaemic cardiovascular risk factors must be a cause for an alarm, furthermore as today's preventive and treatment measures in cardiology, both primary and secondary, are strongly focused on dyslipidaemias.
\end{abstract}

Key words: coronary heart disease, type 2 diabetes mellitus, total cholesterol, LDL-cholesterol, HDL-cholesterol, triglycerides

\section{Introduction}

Type 2 diabetes mellitus is recognized today as one of main public health problems in the world ${ }^{1}$. The role of type 2 diabetes mellitus as one of principal risk factors for the development of cardiovascular disease (CVD) is well investigated ${ }^{2}$. It's continuously rising incidence and prevalence is continually in the focus of attention and it seems to be closely related with western dietary habits, physical inactivity and ever more prevalent obesity. It is well known that, apart from genetic and environmental factors, its development and progression is also influenced by lifestyle, habits and some individual factors, as this has especially profoundly been investigated in type 2 diabetes mellitus ${ }^{3}$. On the other hand, it is encouraging that change of lifestyle and habits can help prevent occurrence of diabetes mellitus, in this context body weight reduction is considered as the main predictor of success in this process ${ }^{4}$. Several studies have shown that in persons with high risk for development of diabetes mellitus it is possible to reduce its incidence through change of lifestyle and habits, mainly with significant reduction of body weight $^{5-8}$, but, as seen in a study from India, even if no significant weight reduction is achieved ${ }^{9}$. European Society of Cardiology (ESC) 2007 Guidelines on management of diabetes mellitus and CVD prevention give recommendations on desired goals in patients with coronary heart disease (CHD) and diabetes mellitus ${ }^{10-13}$, whereas the ESC Guidelines from 2008 give recommendations on desired goals in patients that have had myocardial infarction ${ }^{14}$.

Lipidogram analysis usually involves measurement of four components: total cholesterol, LDL-cholesterol, HDL-cholesterol and triglycerides. Measured levels of all men- 
tioned components if they are increased are considered as risk factors, except in case of HDL-cholesterol, where its decreased measured levels are considered as a risk factor. 2007 ESC Guidelines give recommendations on favourable lipidogram values both for primary and secondary prevention ${ }^{10-13}$, while ESC Guidelines from 2008 give recommendations on desired lipidogram target values in patients that have suffered from a myocardial infarction with ST-segment elevation ${ }^{14}$. Published data in global literature has shown that all four lipidogram components are some of principal risk factors for the development of CVD - increased total cholesterol ${ }^{15,16}$, increased LDL-cholesterol, decreased HDL-cholesterol ${ }^{17}$ and increased triglyceride levels ${ }^{17}$.

\section{Materials and Methods}

The survey included 1,298 patients hospitalized between October $1^{\text {st }} 2007$ and January $7^{\text {th }} 2010$ for acute or chronic CHD in various hospitals in Croatia. It was performed in the above mentioned period in Dubrava University Hospital (Zagreb), Sveti Duh University Hospital (Zagreb), Bjelovar General Hospital, Čakovec General Hospital, Karlovac General Hospital, Koprivnica General Hospital, Slavonski Brod General Hospital, Varaždin General Hospital, Rijeka University Hospital Centre, Pula General Hospital, Split University Hospital Centre, Dubrovnik General Hospital and Zadar General Hospital.

A special questionnaire was produced for this study which allowed recording of required data. Questionnaire was made after series of consultations with experts and literature and it was compiled by model of large clinical trials conducted in Europe and Croatia [INTERHEART ${ }^{18}$, EUROASPIRE (European action on secondary prevention by intervention to reduce events) $\mathrm{I}^{19}$ and $\mathrm{II}^{20}$, EH-UH (Epidemiology of hypertension in Croatia) ${ }^{21}$, TASPIC-CRO (Treatment and secondary prevention of ischemic coronary events in Croatia) ${ }^{22}$ ]. This allowed the investigators to be able to efficiently compare results. Most of the questions had multiple answers offered in advance to acquire greater accuracy. Data was collected on patient history (personal and family history), age, sex and information on cardiovascular risk factors and discharge diagnoses. Physical examination was performed and its find- ings were recorded. Special focus in the questionnaire was on diabetes mellitus and dyslipidaemia. It was possible to measure the presence of these risk factors as the following laboratory data was recorded in the questionnaire: blood glucose levels with information on duration of fasting and previously diagnosed diabetes mellitus and lipidogram with values of total cholesterol, LDL-cholesterol, HDL-cholesterol and triglycerides.

Categories used in recording of presence of diabetes mellitus included: normal blood glucose levels, glucose intolerance and diabetes mellitus - as defined according to World Health Organization (WHO) 1999 Guidelines. Glucose concentrations lower than $6.1 \mathrm{mmol} / \mathrm{L}$ after fasting, or $7.8 \mathrm{mmol} / \mathrm{L}$ after meal were considered as normal. Glucose concentrations between $6.1 \mathrm{mmol} / \mathrm{L}$ and $7 \mathrm{mmol} / \mathrm{L}$ after fasting and between $7.8 \mathrm{mmol} / \mathrm{L}$ and $11 \mathrm{mmol} / \mathrm{L}$ after meal were considered as indicative of glucose intolerance. Values of glucose concentrations higher than 7 $\mathrm{mmol} / \mathrm{L}$ after fasting, or $11.1 \mathrm{mmol} / \mathrm{L}$ after meal were considered as indicative of diabetes mellitus ${ }^{12,13,23}$. Patients with previously diagnosed diabetes mellitus were considered as having diabetes mellitus regardless of recorded glucose concentrations.

Presence of dyslipidaemia was defined according to currently valid Guidelines ${ }^{10,11,13,14}$ : in patients which were already taking statins, or as presence of LDL cholesterol concentration equal to or higher than $2.5 \mathrm{mmol} / \mathrm{L}$ in morning blood sample after period of 12 hours with no food intake, or as total cholesterol concentration equal to or higher than $4.5 \mathrm{mmol} / \mathrm{L}$. Triglyceride concentration equal to or higher than $1.7 \mathrm{mmol} / \mathrm{L}$ and HDL cholesterol concentration less than $1 \mathrm{mmol} / \mathrm{L}$ in men and $1.2 \mathrm{mmol} / \mathrm{L}$ in women were considered as markers of increased cardiovascular risk.

Data were collected by physicians or trained personnel (nurse), coded and entered into the electronic file. Confidentiality of data was ensured in accordance with current applicable codes, declarations and other provisions. The results are shown in tables, and for quantitative variables descriptive statistics were done with appropriate measures of central tendency and variability (mean, standard deviation, medians, associated interquartile ranges). Normal distribution of quantitative variables was tested by Kolmogorov-Smirnov test, and then

TABLE 1

DISTRIBUTION OF SELECTED LABORATORY AND ANTHROPOMETRIC VARIABLES IN SUBJECTS

\begin{tabular}{|c|c|c|c|c|c|c|c|c|}
\hline \multirow[t]{2}{*}{ Selected variables } & \multirow{2}{*}{$\mathrm{N}$} & \multirow{2}{*}{ Mean } & \multirow{2}{*}{ SD } & \multirow{2}{*}{ Min. } & \multicolumn{3}{|c|}{ Percentiles } & \multirow{2}{*}{ Max. } \\
\hline & & & & & 25. & 50. (Median) & 75. & \\
\hline Serum glucose $(\mathrm{mmol} / \mathrm{L})$ & 1220 & 7.42 & 3.49 & 0.50 & 5.56 & 6.40 & 8.00 & 53.00 \\
\hline Serum total cholesterol (mmol/L) & 1177 & 5.37 & 1.40 & 1.59 & 4.40 & 5.30 & 6.20 & 15.21 \\
\hline Serum HDL-cholesterol (mmol/L) & 1088 & 1.22 & 0.49 & 0.43 & 0.96 & 1.14 & 1.39 & 8.30 \\
\hline Serum LDL-cholesterol (mmol/L) & 1059 & 3.30 & 1.14 & 0.42 & 2.43 & 3.24 & 4.00 & 8.80 \\
\hline Serum triglycerides $(\mathrm{mmol} / \mathrm{L})$ & 1166 & 2.05 & 1.52 & 0.33 & 1.22 & 1.76 & 2.39 & 26.25 \\
\hline
\end{tabular}

$\mathrm{N}$ - number, SD - standard deviation, Min. - minimum, Max. - maximum, mmol/L - millimoles per litre, HDL - high density lipoprotein, LDL - low density lipoprotein 
appropriate parametric (t-test for independent samples and analysis of variance - ANOVA) or nonparametric tests (Mann-Whitney U test, Kruskal-Wallis test) were used. The $\chi^{2}$ test was also used.

Statistically significant results were considered those with $\mathrm{p}$ values $<0.05$. Statistical analysis was made using the software PASW version 17.02 (Chicago Inc., IL, www. spss.com).

\section{Results}

Table 1 shows the distribution of measured laboratory and anthropometric variables in the whole sample. Mean serum glucose levels were $7.42 \pm 3.49 \mathrm{mmol} / \mathrm{L}$, mean serum total cholesterol levels were $5.37 \pm 1.40 \mathrm{mmol} / \mathrm{L}$, mean serum HDL-cholesterol levels were $1.22 \pm 0.49 \mathrm{mmol} / \mathrm{L}$, mean serum LDL-cholesterol levels were $3.30 \pm 1.14 \mathrm{mmol} / \mathrm{L}$ and mean serum triglyceride levels were $2.05 \pm 1.52$ $\mathrm{mmol} / \mathrm{L}$. Comparison of these variables by sex is shown in Table 2. Only statistically significant difference was found in serum levels of HDL-cholesterol: in women its level was higher than in men $(1.28 \pm 0.45 \mathrm{mmol} / \mathrm{L}$ vs. $1.19 \pm 0.50 \mathrm{mmol} / \mathrm{L}$, Table $2, \mathrm{p}<0.001$, Mann Whitney U test).

Subjects were divided into 3 groups depending on measured serum glucose levels (measured in $\mathrm{mmol} / \mathrm{L}$ ) based on the data from the current Guidelines, taking into account whether or not they were fasting at the time when the sample was taken. Normal serum glucose levels ( $<6.1$ fasting or $<7.8$ after meal) were recorded in 388 subjects $(46.1 \%)$, glucose intolerance $(6.1-7$ fasting or 7.8-11.1 after meal) was recorded in 188 subjects (22.3\%) and diabetes mellitus ( $>7$ fasting or $>11.1$ after meal) was recorded in 266 subjects (31.6\%). The data on serum glucose level was not available for 456 subjects. Table 3 shows comparison of measured serum glucose levels by sex. Diabetes mellitus was statistically significantly more frequent in women ( $35.7 \%$ vs. $30.0 \%)$, and glucose intolerance was statistically significantly more frequent in men $\left(24.5 \%\right.$ vs. $16.8 \%, \mathrm{p}=0.040, \chi^{2}$-test $)$.

Subjects were also divided into two groups according to the serum total cholesterol levels as recommended by

TABLE 2

SELECTED LABORATORY AND ANTHROPOMETRIC VARIABLES IN SUBJECTS BY SEX

\begin{tabular}{|c|c|c|c|c|c|c|c|c|c|c|}
\hline \multirow{2}{*}{ Selected variables } & \multirow{2}{*}{ Sex } & \multirow{2}{*}{$\mathrm{N}$} & \multirow{2}{*}{ Mean } & \multirow{2}{*}{$\mathrm{SD}$} & \multirow{2}{*}{ Min. } & \multicolumn{3}{|c|}{ Percentiles } & \multirow{2}{*}{ Max. } & \multirow{2}{*}{$\mathrm{p}$} \\
\hline & & & & & & 25. & 50. (Median) & 75. & & \\
\hline \multirow{2}{*}{ Serum glucose (mmol/L) } & Men & 864 & 7,29 & 3.21 & 3.40 & 5.50 & 6.40 & 7.80 & 32.50 & \multirow{2}{*}{0.099} \\
\hline & Women & 356 & 7.73 & 4.06 & 0.50 & 5.59 & 6.51 & 8.60 & 53.00 & \\
\hline \multirow{2}{*}{ Serum total cholesterol (mmol/L) } & Men & 836 & 5.34 & 1.35 & 1.59 & 4.40 & 5.28 & 6.16 & 11.04 & \multirow{2}{*}{0.367} \\
\hline & Women & 341 & 5.45 & 1.49 & 1.80 & 4.39 & 5.37 & 6.20 & 15.21 & \\
\hline \multirow{2}{*}{ Serum HDL-cholesterol (mmol/L) } & Men & 771 & 1.19 & 0.50 & 0.43 & 0.93 & 1.10 & 1.34 & 8.30 & \multirow{2}{*}{$<0.001$} \\
\hline & Women & 317 & 1.28 & 0.45 & 0.47 & 1.01 & 1.20 & 1.46 & 6.41 & \\
\hline \multirow{2}{*}{ Serum LDL-cholesterol (mmol/L) } & Men & 754 & 3.30 & 1.13 & 0.42 & 2.45 & 3.25 & 3.99 & 8.80 & \multirow{2}{*}{0.800} \\
\hline & Women & 305 & 3.30 & 1.18 & 0.79 & 2.41 & 3.20 & 4.05 & 8.57 & \\
\hline \multirow{2}{*}{ Serum triglycerides $(\mathrm{mmol} / \mathrm{L})$} & Men & 832 & 2.09 & 1.62 & 0.40 & 1.23 & 1.77 & 2.40 & 26.25 & \multirow{2}{*}{0.251} \\
\hline & Women & 334 & 1.95 & 1.20 & 0.33 & 1.20 & 1.64 & 2.30 & 11.75 & \\
\hline
\end{tabular}

Mann-Whitney U test was used, $\mathrm{p}<0.05$ is considered statistically significant

$\mathrm{N}$ - number, SD - standard deviation, Min. - minimum, Max. - maximum, mmol/L - millimoles per litre, HDL - high density lipoprotein, LDL - low density lipoprotein

TABLE 3

COMPARISON OF SERUM GLUCOSE CONCENTRATIONS BY SEX

\begin{tabular}{lccc}
\hline & \multicolumn{3}{c}{ Serum glucose concentrations in mmol/L (groups) } \\
\cline { 2 - 4 } Sex & $\begin{array}{c}\text { Normal levels }(<6.1 \text { fasting } \\
\text { or }<7.8 \text { after meal) }\end{array}$ & $\begin{array}{c}\text { Glucose intolerance }(6.1-7 \text { fasting } \\
\text { or } 7.8-11.1 \text { after meal) }\end{array}$ & $\begin{array}{c}\text { Diabetes mellitus }(>7 \text { fasting } \\
\text { or }>11.1 \text { after meal) }\end{array}$ \\
\hline Male & $275(45.5 \%)$ & $148(24.5 \%)$ & $181(30.0 \%)$ \\
Female & $113(47.5 \%)$ & $40(16.8 \%)$ & $85(35.7 \%)$ \\
Total & $388(46.1 \%)$ & $188(22.3 \%)$ & $2604(31.6 \%)$ \\
\hline
\end{tabular}

$\chi^{2}=6.455 ; \mathrm{df}=2 ; \mathrm{p}=0.040$

$\chi^{2}$ test was used, $\mathrm{p}<0.05$ is considered statistically significant

$\mathrm{mmol} / \mathrm{L}$ - millimoles per litre, \% - percent, $\mathrm{df}$ - degrees of freedom 
the Guidelines. One group consisted of subjects with total cholesterol levels $<4.5 \mathrm{mmol} / \mathrm{L}$ (330 subjects, $28.0 \%$ ) and the other group consisted of subjects with total cholesterol levels $\geq 4.5 \mathrm{mmol} / \mathrm{L}$ (847 subjects, $72.0 \%$ ), while the data was not available for 121 subjects. Comparison of serum total cholesterol levels by sex showed no statistically significant differences (Table 4). It is worth mentioning, however, that in both groups more than $70 \%$ of subjects have serum total cholesterol values above those which are recommended by the Guidelines.

Subjects were also divided into two groups in relation to their serum HDL-cholesterol levels - one in which the serum HDL-cholesterol was lower than recommended levels $(\leq 1 \mathrm{mmol} / \mathrm{L}$ in $\mathrm{men}$ and $\leq 1.2 \mathrm{mmol} / \mathrm{L}$ in women; 464 subjects, $42.6 \%$ ) and the other one in which the serum HDL-cholesterol was within the recommended range $(>1 \mathrm{mmol} / \mathrm{L}$ in men and $>1.2 \mathrm{mmol} / \mathrm{L}$ in women, 624 subjects, $57.4 \%)$. The data was not available for 210 subjects. Table 5 shows the comparison of serum HDL-cholesterol values in subjects by sex - there were statistically significantly more female subjects with serum HDL-cholesterol levels below those which are recommended by the Guidelines $\left(50.2 \%\right.$ vs. $39.6 \%, \mathrm{p}=0.001, \chi^{2}$-test).

Subjects were also divided into two groups regarding their serum LDL-cholesterol levels: 293 subjects (27.7\%) had those values within recommended range $(<2.5$ $\mathrm{mmol} / \mathrm{L})$, while in 766 subjects $(72.3 \%)$ those levels were above recommended range ( $\geq 2.5 \mathrm{mmol} / \mathrm{L})$; finally, for 239

TABLE 4

SERUM TOTAL CHOLESTEROL BY SEX

\begin{tabular}{lccc}
\hline \multirow{2}{*}{ Sex } & \multicolumn{2}{c}{ Total cholesterol (groups) } & \multirow{2}{*}{ Total } \\
\cline { 2 - 3 } & $<4.5 \mathrm{mmol} / \mathrm{L}$ & $\geq 4.5 \mathrm{mmol} / \mathrm{L}$ & \\
\hline Male & $237(28.3 \%)$ & $599(71.7 \%)$ & $836(100.0 \%)$ \\
Female & $93(27.3 \%)$ & $248(72.7 \%)$ & $341(100.0 \%)$ \\
Total & $330(28.0 \%)$ & $847(72.0 \%)$ & $1177(100.0 \%)$ \\
\hline
\end{tabular}

$\chi^{2}=0.139 ; \mathrm{df}=1 ; \mathrm{p}=0.709$

$\chi^{2}$-test was used, $\mathrm{p}<0.05$ is considered statistically significant $\mathrm{mmol} / \mathrm{L}$ - millimoles per litre, $\%$ - percent, $\mathrm{df}$ - degrees of freedom

TABLE 5

SERUM HDL-CHOLESTEROL BY SEX

\begin{tabular}{lccr}
\hline & \multicolumn{2}{c}{ HDL-cholesterol (groups) } & \\
\cline { 2 - 3 } Sex & Low & $\begin{array}{c}\text { Normal } \\
\text { Total }\end{array}$ & Tot \\
& $\begin{array}{c}\mathrm{M} \leq 1 \mathrm{mmol} / \mathrm{L}, \\
(\mathrm{M}>1.2 \mathrm{mmol} / \mathrm{L})\end{array}$ & $\mathrm{F}>1.2 \mathrm{mmol} / \mathrm{L})$ & \\
\hline Male & $305(39.6 \%)$ & $466(60.4 \%)$ & $771(100.0 \%)$ \\
Female & $159(50.2 \%)$ & $158(49.8 \%)$ & $317(100.0 \%)$ \\
Total & $464(42.6 \%)$ & $624(57.4 \%)$ & $1088(100.0 \%)$ \\
\hline
\end{tabular}

$\chi^{2}=10.317 ; \mathrm{df}=1 ; \mathrm{p}=0.001$

$\chi^{2}$-test was used, $\mathrm{p}<0.05$ is considered statistically significant $\mathrm{mmol} / \mathrm{L}$ - millimoles per litre, HDL - high density lipoprotein, \% - percent, df - degrees of freedom, M - men, F - women
TABLE 6

SERUM LDL-CHOLESTEROL BY SEX

\begin{tabular}{lccr}
\hline Sex & \multicolumn{2}{c}{ LDL-cholesterol (groups) } & \multirow{2}{*}{ Total } \\
\cline { 2 - 3 } & $<2.5 \mathrm{mmol} / \mathrm{L}$ & $\geq 2.5 \mathrm{mmol} / \mathrm{L}$ & \\
\hline Male & $208(27.6 \%)$ & $546(72.4 \%)$ & $754(100.0 \%)$ \\
Female & $85(27.9 \%)$ & $220(72.1 \%)$ & $305(100.0 \%)$ \\
Total & $293(27.7 \%)$ & $766(72.3 \%)$ & $1059(100.0 \%)$ \\
\hline
\end{tabular}

$\chi^{2}=0.009 ; \mathrm{df}=1 ; \mathrm{p}=0.926$

$\chi^{2}$-test was used, $\mathrm{p}<0.05$ is considered statistically significant $\mathrm{mmol} / \mathrm{L}$ - millimoles per litre, LDL - low density lipoprotein, \% percent, $\mathrm{df}$ - degrees of freedom

TABLE 7

SERUM TRIGLYCERIDES BY SEX

\begin{tabular}{lccr}
\hline \multirow{2}{*}{ Sex } & \multicolumn{2}{c}{ Triglycerides (groups) } & \multirow{2}{*}{ Total } \\
\cline { 2 - 3 } & $<1.7 \mathrm{mmol} / \mathrm{L}$ & $\geq 1.7 \mathrm{mmol} / \mathrm{L}$ & \\
\hline Male & $393(47.2 \%)$ & $439(52.8 \%)$ & $832(100.0 \%)$ \\
Female & $172(51.5 \%)$ & $162(48.5 \%)$ & $334(100.0 \%)$ \\
Total & $565(48.5 \%)$ & $601(51.5 \%)$ & $1166(100.0 \%)$ \\
\hline
\end{tabular}

$\chi^{2}=1.733 ; \mathrm{df}=1 ; \mathrm{p}=0.188$

$\chi^{2}$-test was used, $\mathrm{p}<0.05$ is considered statistically significant $\mathrm{mmol} / \mathrm{L}$ - millimoles per litre, \% - percent, $\mathrm{df}$ - degrees of freedom

subjects the data were not available. There were no statistically significant differences between sexes (Table 6).

Finally, 565 subjects $(48.5 \%)$ had serum triglyceride levels within the recommended range $(<1.7 \mathrm{mmol} / \mathrm{L})$ and $601(51.5 \%)$ subjects had those values above the recommended range $(\geq 1.7 \mathrm{mmol} / \mathrm{L})$, the data was not available for 132 subjects. There were no statistically significant differences between sexes (Table 7).

\section{Discussion}

This article investigated prevalences of two well-known cardiovascular risk factors - diabetes mellitus and dyslipidaemia (total cholesterol, HDL-cholesterol, LDL-cholesterol and triglycerides) in the population of hospitalized Croatian CHD patients. As Croatia was one of the countries which participated in the European action on secondary prevention by intervention to reduce events (EUROASPIRE) III study performed in 22 European countries in $2006^{24}$, it is possible to compare this data with both Croatian and European data from that study. Furthermore, valuable data on hospitalized Croatian CHD patients was presented in Treatment and secondary prevention of ischemic coronary events in Croatia (TASPIC-CRO) V study which was performed in Croatia in 2002 and $2003^{22}$.

Diabetes mellitus has been shown to be one of major risk factors for the development of $\mathrm{CHD}^{2}$ and is certainly one of largest public health problems in the world today ${ }^{1}$. In this study, $46.1 \%$ of subjects had normal serum glucose levels, while $31.6 \%$ had diabetes mellitus (Table 3 ). 
While this finding does demonstrate a further increase in comparison with the recorded prevalence of diabetes mellitus in TASPIC-CRO V study $(30 \%)^{22}$, it is still an improvement when compared with the reported prevalence of diabetes mellitus in EUROASPIRE III study, which reported prevalence of diabetes mellitus of $34.8 \%$ in Europe and $35.3 \%$ in Croatia ${ }^{24}$. Statistically significantly more women than men had diabetes mellitus ( $35.7 \%$ vs. $30.0 \%, p=0.040$, Table 3) and interestingly, this statistically significant difference between sexes has also been observed TASPIC-CRO V study ( $28 \%$ of men and $34 \%$ of women had diabetes) ${ }^{22}$.

Assessment of the level of influence of a dyslipidaemia usually involves analysis of four main lipidogram components: total cholesterol, LDL-cholesterol, HDL-cholesterol and triglycerides. Levels above those recommended by the Guidelines for total cholesterol, LDL-cholesterol and triglycerides represent a cardiovascular risk factor, while levels of HDL-cholesterol below those recommended by the Guidelines also represent an established cardiovascular risk factor ${ }^{15-17}$.

Unfortunately, as much as $72.0 \%$ of subjects in this study had total cholesterol levels higher than those recommended by current ESC Guidelines. This represents further increase in prevalence of this risk factor, as it's prevalence in TASPIC-CRO V study was $69 \%^{22}$ and in EUROASPIRE III study considerably less $(52 \%)^{24}$. Although there were no statistically significant differences between sexes, this represents a change, as in TASPIC-CRO V study the total cholesterol above recommended levels was recorded more frequently in women than in men $^{22}$.

Levels of HDL-cholesterol which were too low according to the current Guidelines were found in $42.6 \%$ of subjects, and this was more frequently the case in women (Table 5, 50.2\% vs. 39.6\%). When these data are compared to both other relevant studies, one can see that the prevalence of this risk factor is increasing. In EUROASPIRE III study the prevalence was $36.7 \%$ in Europe and $34.1 \%$ in Croatia ${ }^{24}$; while in TASPIC-CRO V study it was $42 \%{ }^{22}$. Contrary to results from our study, in TASPIC-CRO V study values of HDL-cholesterol lower than those recommended by the guidelines were more frequently present in men $^{22}$.

A similar result was found when the data on prevalence of raised LDL-cholesterol was analysed - as much as $72.3 \%$ of subjects were in this group. This again repre- sents a further increase in prevalence (in TASPIC-CRO $\mathrm{V}$ study the prevalence was $69 \%)^{22}$. There were no statistically significant differences between sexes in prevalence of this risk factor, however, it was, like for total cholesterol, reported in TASPIC-CRO V study that this risk factor was more frequently present in women ${ }^{22}$. One could speculate that the difference between sexes had been annulated by higher increase in prevalence of increased total cholesterol and LDL-cholesterol in men than in women.

More than half of the subjects $(51.5 \%)$ had triglyceride levels higher than those recommended by the Guidelines, while there were no statistically significant differences between sexes. Knowing that in TASPIC-CRO V study only $37 \%$ of subjects had this risk factor ${ }^{22}$ and in EUROASPIRE III it was present in $49.9 \%$ of subjects in Croatia (it was 51.5\% on the level of European sample $)^{24}$, one can see a clear rise in it prevalence. This is an alarming sign, as it means that we are closer than ever to the European prevalences.

Reported data on prevalences of diabetes mellitus can be somewhat reassuring (as they represent a decrease in its prevalence compared to data from 2006, but they still signal a situation which is a lot worse than in 2002 and 2003); the trend of rising prevalences of dyslipidaemic cardiovascular risk factors must be a cause for an alarm, furthermore as today's preventive and treatment measures in cardiology, both primary and secondary, are strongly focused on dyslipidaemias. One would expect that with ever-increasing use of drugs and other interventions, those prevalences would show a stable decreasing trend. However, our data suggests this is still not the case. One can only speculate what those prevalences would be like if our society was not combating these risk factors at all.

\section{Acknowledgements}

This study was supported by the Ministry of Science, Education and Sports of the Republic of Croatia, project number 108-1080135-126 (Risk factors by region in hospitalised coronary heart disease patients, led by prof. Mijo Bergovec) which is a part of a programme of projects number 1080135 (Regionalism, dynamics of cardiovascular risk factors and health interventions, led by prof. Mijo Bergovec).

\section{R E F E R E N C E S}

1. KING H, AUBERT RE, HERMAN WH, Diabetes Care, 21 (1998) 1414. - 2. PYORALA K, LAAKSO M, UUSITUPA M, Diabetes Metab Rev, 3 (1987) 463. - 3. MENSINK M, CORPELEIJN E, FESKENS EJ, KRUIJSHOOP M, SARIS WH, DE BRUIN TW, BLAAK EE, Diabetes Res Clin Pract, 61 (2003) 49. - 4. AMERICAN DIABETES ASSOCIATION, BANTLE JP, WYLIE-ROSETT J, ALBRIGHT AL, APOVIAN CM, CLARK NG, FRANZ MJ, HOOGWERF BJ, LICHTENSTEIN AH MAYER-DAVIS E, MOORADIAN AD, WHEELER ML, Diabetes Care, 31 Suppl 1 (2008) S61. - 5. PAN XR, LI GW, HU YH, WANG JX, YANG WY,

AN ZX, HU ZX, LIN J, XIAO JZ, CAO HB, LIU PA, JIANG XG, JIANG YY, WANG JP, ZHENG H, ZHANG H, BENNETT PH, HOWARD BV, Diabetes Care, 20 (1997) 537. - 6. TUOMILEHTO J, LINDSTRÖM J, ERIKSSON JG, VALLE TT, HÄMÄLÄINEN H, ILANNE-PARIKKA P, KEINÄNEN-KIUKAANNIEMI S, LAAKSO M, LOUHERANTA A, RASTAS M, SALMINEN V, UUSITUPA M, FINNISH DIABETES PREVENTION STUDY GROUP, N Engl J Med, 344 (2001) 1343. - 7. KOSAKA K, NODA M, KUZUYA T, Diabetes Res Clin Pract, 67 (2005) 152. - 8. KNOWLER WC, BARRETT-CONNOR E, FOWLER SE, HAMMAN RF, 
LACHIN JM, WALKER EA, NATHAN DM, DIABETES PREVENTION PROGRAM RESEARCH GROUP, N Engl J Med, 346 (2002) 393. — 9 RAMACHANDRAN A, SNEHALATHA C, MARY S, MUKESH B, BHASKAR AD, VIJAY V, INDIAN DIABETES PREVENTION PROGRAMME (IDPP), Diabetologia, 49 (2006) 289. - 10. GRAHAM I, ATAR D, BORCH-JOHNSEN K, BOYSEN G, BURELL G, CIFKOVA R, DALLONGEVILLE J, DE BACKER G, EBRAHIM S, GJELSVIK B, HERRMANN-LINGEN C, HOES A, HUMPHRIES S, KNAPTON M, PERK J, PRIORI SG, PYORALA K, REINER Z, RUILOPE L, SANS-MENENDEZ S, SCHOLTE OP REIMER W, WEISSBERG P, WOOD D, YARNELL J, ZAMORANO JL, WALMA E, FITZGERALD T, COONEY MT, DUDINA A, EUROPEAN SOCIETY OF CARDIOLOGY (ESC) COMMITTEE FOR PRACTICE GUIDELINES (CPG), Eur Heart J, 28 (2007) 2375. - 11 GRAHAM I, ATAR D, BORCH-JOHNSEN K, BOYSEN G, BURELL G CIFKOVA R, DALLONGEVILLE J, DE BACKER G, EBRAHIM S, GJELSVIK B, HERRMANN-LINGEN C, HOES A, HUMPHRIES S, KNAPTON M, PERK J, PRIORI SG, PYORALA K, REINER Z, RUILOPE L, SANS-MENENDEZ S, OP REIMER WS, WEISSBERG P, WOOD D, YARNELL J, ZAMORANO JL, WALMA E, FITZGERALD T, COONEY MT, DUDINA A, VAHANIAN A, CAMM J, DE CATERINA R, DEAN V, DICKSTEIN K, FUNCK-BRENTANO C, FILIPPATOS G, HELLEMANS I, KRISTENSEN SD, MCGREGOR K, SECHTEM U, SILBER S, TENDERA M, WIDIMSKY P, ZAMORANO JL, ALTINER A, BONORA E, DURRINGTON PN, FAGARD R, GIAMPAOLI S, HEMINGWAY H, HAKANSSON J, KJELDSEN SE, LARSEN L, MANCIA G, MANOLIS AJ, ORTH-GOMER K, PEDERSEN T, RAYNER M, RYDEN L, SAMMUT M, SCHNEIDERMAN N, STALENHOEF AF, TOKGÖZOGLU L, WIKLUND O, ZAMPELAS A, EUROPEAN SOCIETY OF CARDIOLOGY (ESC), EUROPEAN ASSOCIATION FOR CARDIOVASCULAR PREVENTION AND REHABILITATION (EACPR), COUNCIL ON CARDIOVASCULAR NURSING, EUROPEAN ASSOCIATION FOR STUDY OF DIABETES (EASD), INTERNATIONAL DIABETES FEDERATION EUROPE (IDF-EUROPE), EUROPEAN STROKE INITIATIVE (EUSI), SOCIETY OF BEHAVIOURAL MEDICINE (ISBM), EUROPEAN SOCIETY OF HYPERTENSION (ESH), WONCA EUROPE (EUROPEAN SOCIETY OF GENERAL PRACTICE/FAMILY MEDICINE), EUROPEAN HEART NETWORK (EHN), EUROPEAN ATHEROSCLEROSIS SOCIETY (EAS), Eur J Cardiovasc Prev Rehabil, 14 (2007) S1. - 12. GRUPO DE TRABAJO SOBRE DIABETES Y ENFERMEDADES CARDIOVASCULARES DE LA SO CIEDAD EUROPEA DE CARDIOLOGÍA Y DE LA SOCIEDAD EUROPEA PARA EL ESTUDIO DE LA DIABETES, RYDÉN L, STANDL E,
BARTNIK M, VAN DEN BERGHE G, BETTERIDGE J, DE BOER MJ, COSENTINO F, JÖNSSON B, LAAKSO M, MALMBERG K, PRIORI S, OSTERGREN J, TUOMILEHTO J, THRAINSDOTTIR I, Rev Esp Cardiol, 60 (2007) 1e. - 13. RYDÉN L, STANDL E, BARTNIK M, VAN DEN BERGHE G, BETTERIDGE J, DE BOER MJ, COSENTINO F, JÖNSSON B, LAAKSO M, MALMBERG K, PRIORI S, OSTERGREN J, TUOMILEHTO J, THRAINSDOTTIR I, VANHOREBEEK I, STRAMBA-BADIALE M, LINDGREN P, QIAO Q, PRIORI SG, BLANC JJ, BUDAJ A, CAMM J, DEAN V, DECKERS J, DICKSTEIN K, LEKAKIS J, MCGREGOR K, METRA M, MORAIS J, OSTERSPEY A, TAMARGO J, ZAMORANO JL, DECKERS JW, BERTRAND M, CHARBONNEL B, ERDMANN E, FERRANNINI E, FLYVBJERG A, GOHLKE H, JUANATEY JR, GRAHAM I, MONTEIRO PF, PARHOFER K, PYÖRÄLÄ K, RAZ I, SCHERNTHANER G, VOLPE M, WOOD D, TASK FORCE ON DIABETES AND CARDIOVASCULAR DISEASES OF THE EUROPEAN SOCIETY OF CARDIOLOGY (ESC), EUROPEAN ASSOCIATION FOR THE STUDY OF DIABETES (EASD), Eur Heart J, 28 (2007) 88. - 14. VAN DE WERF F, BAX J, BETRIU A, BLOMSTROM-LUNDQVIST C, CREA F, FALK V, FILIPPATOS G, FOX K, HUBER K, KASTRATI A, ROSENGREN A, STEG PG, TUBARO M, VERHEUGT F, WEIDINGER F, WEIS M; ESC COMMITTEE FOR PRACTICE GUIDELINES (CPG), Eur Heart J, 29 (2008) 2909. - 15. THE POOLING PROJECT RESEARCH GROUP, J Chronic Dis, 31 (1978) 201. - 16. NEATON JD, BLACKBURN H, JACOBS D, KULLER L, LEE DJ, SHERWIN R, SHIH J, STAMLER J, WENTWORTH D, Arch Intern Med, 152 (1992) 1490. - 17. HALL WH, JAMA, 269 (1993) 505. - 18. YUSUF S, HAWKEN S, OUNPUU S, DANS T, AVEZUM A, LANAS F, MCQUEEN M, BUDAJ A, PAIS P, VARIGOS J, LISHENG L, INTERHEART STUDY INVESTIGATORS, Lancet, 364 (2004) 937. — 19. EUROASPIRE STUDY GROUP, Eur Heart J, 18 (1997) 1569. - 20. EUROASPIRE II STUDY GROUP, Eur Heart J, 22 (2001) 554. - 21. JELAKOVIC B, ZELJKOVIC-VRKIC T, PECIN I, DIKA Z, JOVANOVIC A, PODOBNIK D, SMUC T, GAMBERGER D, KATIC K, KASNER M, KUZMANIC D; EH-UH ISTRAZIVACKE SKUPINE, Acta Med Croatica, 61 (2007) 287. - 22. REINER Z, MIHATOV S, MILICIC D, BERGOVEC M, PLANINC D, TASPIC-CRO STUDY GROUP INVESTIGATORS, Eur J Cardiovasc Prev Rehabil, 13 (2006) 646. - 23. CONSULTATION WHO. Definition, diagnosis and classification of diabetes mellitus and its complications. Part 1: Diagnosis and classification of diabetes mellitus (WHO, Geneva, 1981). - 24. KOTSEVA K, WOOD D, DE BACKER G, DE BACQUER D, PYÖRÄLÄ K, KEIL U, EUROASPIRE STUDY GROUP, Eur J Cardiovasc Prev Rehabil, 16 (2009) 121.

\section{H. Vražić}

University of Zagreb, Dubrava University Hospital, Department of Internal Medicine, Division of Cardiology, Av. G. Šuška 6, 10000 Zagreb, Croatia

e-mail:vrazic@gmail.com

\section{PREVALENCIJA ŠEĆERNE BOLESTI I POREMEĆENIH VRIJEDNOSTI LIPIDOGRAMA U HOSPITALIZIRANIH KORONARNIH BOLESNIKA U HRVATSKOJ}

\section{S A Ž E T A K}

Cilj ovog rada bio je pokazati prevalenciju šećerne bolesti i poremećenih vrijednosti lipidograma uz izabrane antropometrijske varijable na uzorku bolesnika hospitaliziranih zbog koronarne bolesti u Republici Hrvatskoj $(\mathrm{N}=1.298)$. Prevalencija šećerne bolesti iznosila je 31,6\% (statistički znatno češća u žena, 35,7\% prema 30,0\%), dok su prevalencije povišenog ukupnog kolesterola iznosile 72,0\%, smanjenog HDL-kolesterola 42,6\% (statistički znatno češći u žena, 50,2\% prema $39,6 \%$ ), povišenog LDL-kolesterola $72,3 \%$ i povišenih triglicerida $51,5 \%$. Iako ovdje prikazani podaci vezani uz učestalost šećerne bolesti mogu biti donekle ohrabrujući (budući da pokazuju smanjenje prevalencije šećerne bolesti u usporedbi sa podacima iz 2006. g., no svejedno pokazuju puno goru situaciju u odnosu na onu iz 2002. i 2003. g.); trend rastućih prevalencija dislipidemijskih kardiovaskularnih čimbenika rizika mora biti znakom za uzbunu, tim više jer su današnje mjere prevencije i liječenja, primarne i sekundarne, snažno usredotočene na dislipidemije. 